\title{
Re-creating the hybrid text: postcolonial Indian writings and the European scene
}

\author{
Mary Snell-Hornby \\ Universität Wien
}

For a language with a wealth of great literature such as English, globalization has been a mixed blessing. The International English of McWorld is a poor descendant of the language of Shakespeare and Dickens. On the other hand, English literature has been tremendously enriched by writings from the former colonies of the British Empire, creating their own 'norms' of English - 'a new English', as Chinua Achebe famously put it, "still in full communion with its ancestral home, but altered to suit its new surroundings". In the postcolonial literary scene, such 'hybrid' texts - or 'métissés' - are now a familiar feature, but a complicated one for translators working into other European languages. This essay concentrates on India, and looking at writings by Sethu (Pandavapuram in English translation) and Arundhati Roy (The God of Small Things in English and in German translation), it investigates the striking features of hybrid source texts and the cultural and linguistic problems involved in re-creating them for a European target culture.

\section{The postcolonial hybrid text}

Littledemons were mudbrown in Airport Fairy frocks with forehead bumps that might turn into horns. With Fountains in Love-in-Tokyos. And backward-reading habits.

And if your cared to look, you could see Satan in their eyes.

Kochu Maria took both Sophie's hands in hers, palms upward, raised them to her face and inhaled deeply.

"What's she doing?" Sophie wanted to know, tender London hands clasped in calloused Ayemenem ones.

"Who's she and why's she smelling my hands?"

"She's the cook," Chacko said. "That's her way of kissing you."

"Kissing?" Sophie Mol was unconvinced, but interested.

"How marvellous!" Margaret Kochamma said, "It's a sort of sniffing! Do the men and women do it to each other too?"

She hadn't meant it to sound quite like that, and she blushed. An embarrassed schoolteacher-shaped hole in the Universe.

"Oh, all the time!" Ammu said, and it came out louder than the sarcastic mumble that she had intended.

"That's how we make babies."

This passage is taken from the novel The God of Small Things - world bestseller and winner of the 1997 Booker Prize - by the Indian writer Arundhati Roy (1997: 179). Along with Sahman Rushdie's Midnight's Children and 
The Moor's Last Sigh it has become one of the best known novels on postcolonial India. It is also an example of what is understood here as a hybrid text, one written by the ex-colonized in the language of the ex-colonizer, which has created a 'new language' and has come to occupy a space 'in between'. The definition used here is taken from the essay "Translation and the colonial experience" published in 1992 by Sandra Mehrez, who comments on the hybrid text more explicitly as follows:

Indeed, the emergence and continuing growth on the world literary scene of postcolonial anglophone and francophone literatures from the ex-colonies as well as the increasing ethnic minorities in the First World metropoles are bound to change and redefine many accepted notions in translation theory which continue to be debated and elaborated within the longstanding traditions of western 'humanism' and 'universalism'. These postcolonial texts, frequently referred to as 'hybrid' or 'métissés' because of the culturo-linguistic layering which exists within them, have succeeded in forging a new language that defies the very notion of a 'foreign' text that can be readily translatable into another language. With this literature we can no longer merely concern ourselves with conventional notions of linguistic equivalence, or ideas of loss and gain which have long been a consideration in translation theory. For these texts written by postcolonial bilingual subjects create a language 'in between' and therefore come to occupy a space 'in between'. In most cases, the challenge of such space 'in between' has been double: these texts seek to decolonize themselves from two oppressors at once, namely the western ex-colonizer who naively boasts of their existence and ultimately recuperates them and the 'traditional', 'national' cultures which shortsightedly deny their importance and consequently marginalize them.

(Mehrez 1992: 121)

Mehrez devotes her essay to the francophone North African text, but many of her observations apply equally to the anglophone scene, where such 'hybrid texts' were for some time, though rather misleadingly, classified as "Commonwealth literature" (see Schäfer 1981: 7). In memorable words, the Nigerian writer Chinua Achebe described the language suitable to be used by the African writer as a vehicle of expression in postcolonial English literature: "The African should aim at fashioning out an English which is at once universal and able to carry his peculiar experience. It will have to be a new English, still in full communion with its ancestral home, but altered to suit its new surroundings" (qtd. in Villareal 1994: 62).

Similar statements have been made about Indian postcolonial literature. Prasad (1999) quotes several sources, including Salman Rushdie's claim that English "needs remaking for our own purposes" (qtd. in Prasad 1999: 41), and he also cites the foreword of the novel Kanthapura (first published in 1938) by Raja Rao, who refers to the problem of conveying "in a language not one's own the spirit that is one's own" (qtd. in Prasad 1999: 42). The result is not what is now known as 'Indian English' but a hybrid text occupying that 'space in between', also known as the "Third Space" (Bhaba 1994), involving elements translated from Indian languages: 
In other words the writers do not write in an Indian English or even in their own English but in an English intended to approximate the thought-structures and speech patterns of their characters and not to betray the Indian text and context by an easy assimilation into the linguistic and cultural matrices of British English. (Prasad 1999: 43)

As an example of such a text Prasad takes a passage from Salman Rushdie's Midnight's Children, of which the first paragraph is quoted here:

Padma's story (given in her own words, and read back to her for eye-rolling, high-wailing, mammary-thumping confirmation): "It was my own foolish pride and vanity, Saleem baba, from which cause I did run from you, although the job here is good, and you so much needing a looker-after! But in a short time only I was dying to return." (Rushdie 1981:192-3)

For the European reader this seems to be typical Rushdie language, from the complex adjectival phrases ("eye-rolling, high-wailing, mammary-thumping..."), to the mix of formal and familiar registers ("confirmation", "foolish pride" beside "dying to return") and the creation of new words ("looker-after"). The scholar proficient in Indian languages can recognize various kinds of signals and deviations in their relationship to the Indian setting, from the form of address "Saleem baba" ('baba' as used by servants for young boys of higher social status, also as a term of affection) to the phrase "from which cause I did run from you", recognizable as a structure literally transcoded from Hindustani/Urdu. The author thus locates his character "in terms of region, class and gender through the construction of a specific English using the strategies and resources of a translator" (Prasad 1999: 53). It is devices such as these that characterize the postcolonial Indian hybrid text.

\section{The hybrid text of globalization}

In recent years the concept of hybridity has been extended to include nonliterary texts resulting from business transactions, cultural exchanges or political interaction, e.g. within the institutions of the European Union or the United Nations. Such forms of communication have led to the emergence of the type of hybrid text as defined by Christina Schäffner and Beverly Adab (1997). In their view, hybrid texts result from a translation process and are characterized by features (vocabulary, syntax, style etc.) that clash with target language conventions and are "somehow contrary to the norms of the target language and culture" (Schäffner \& Adab 1997: 327). They also include EU texts that do not necessarily involve translation:

In the process of establishing political unity, linguistic expressions are levelled to a common, (low) denominator. Eurotexts reflect a Euro jargon, i.e. a reduced vocabulary, meanings that tend to be universal, reduced inventory of grammatical forms. When EU legal texts are translated and subsequently 
become embedded in national legislation, they are formative elements in language change in the national languages of the member states. [...]

Acceptance is due to the limited communicative functions of the texts. EU texts, for example, function within the community within which they are created (e.g. for the staff, or for meetings of the respective bodies). This means that there are clearly defined user needs. The multinational EU institutions as such are the target culture, hybrid texts are formative elements in creating a (truly) supranational culture. What counts as knowledge or norms is determined by the respective internal discourse practices.

(Schäffner \& Adab 1997: 327-8)

On the global level such features are even more glaringly evident. There are various reasons for the role of world lingua franca which English has assumed: apart from the world-wide domination of North American technology and culture, there is above all the fact that the basic grammar and core vocabulary of English required for everyday conversations and superficial forms of communication between speakers of other languages, can be relatively easily acquired. The result is 'International English', this being at its worst what has been dubbed 'BSE' (for Bad Simple English, see Stickel 2003) and in general what I have described as a linguistic 'McWorld' with its own 'McLanguage' - typically a variant of American English:

It is however a particular brand of American English, reduced in stylistic range and subject matter, and - with the aid of abbreviations, icons, acronyms and graphic design - tailor-made for fast consumption. It is itself a lingua franca, often colloquial in register even when in written form, and it has no great concern for native-speaker prescriptivism. It functions as a basic common denominator for supra-cultural communication as a kind of free-floating sign system open to all kinds of interferences from other languages according to the background and the linguistic competence of the writers all over the world. (Snell-Hornby 1999: 104-105)

What emerges is a type of hybrid text ranging from the Eurotexts described by Schäffner and Adab (for a UN equivalent see "Note on Morocco's Nuclear Power Programme" as discussed in Snell-Hornby 2000: 39-40) to the endless list of defective notices from all over the world that produce an unintended comic effect and are often quoted as jokes. The following directives found recently in Brazilian hotels, both of them English versions of Portuguese source texts, may serve as examples: "Firewood sauna schedule ask the front desk" and "Warning: Before getting in, make sure the lift is in this floor". While the latter reflects the lack of logic and precise wording of the source text, the former merely requires a preposition and a connective ("For firewood and sauna schedule ask at the front desk"). A final example: every new arrival at Vienna International Airport is greeted by large mats bearing the logo of MasterCard and the message "Vienna waits for you", recognizable as a direct transcoding of "Wien wartet auf Sie". The verb wait for normally requires an animate agent, and - strictly speaking - the intended message should read "Vienna awaits you". 
Such hybridity is not our concern here, but what emerges from the above discussion and examples, is that the hybrid texts of globalization are rather limited in form and function. They result from basic communication needs, and as such, they are tolerated rather than welcomed. The literary postcolonial hybrid text on the other hand shows, in Rushdie's words, that through the process of translation "something can also be gained" (qtd. in Prasad 1999: 41). Indeed, as Prasad comments: "This gain is mirrored in the pollinated and enriched language (and culture) that results from the act of translation - the act not just of bearing across but of fertile coming together".

\section{The concept of the "model reader"}

For the EU hybrid texts Schäffner \& Adab (1997) identified the "multinational EU institutions as such" as the target culture. For the postcolonial hybrid texts, particularly within the context of their re-creation through translation, the question of the target culture is of paramount interest. However, as is the case with literary texts generally, the target audience of postcolonial hybrid texts cannot simply be equated with a general target culture, or market. This issue of readership requires further consideration. In her five-step functional model of translation criticism, Margret Ammann (1990) applies the concept of scenes and frames, as introduced by Fillmore (1977), and developed for translation by Vannerem \& Snell-Hornby (1986) and Vermeer \& Witte (1990). She also adopts the notion of "lettore modello" or "model reader" presented by Umberto Eco. Ammann defines such a reader as a person,

[...] der aufgrund einer Lesestrategie zu einem bestimmten Textverständnis kommt. Seine Lesestrategie zielt auf eine Gesamtscene (als Gesamtverständnis) eines Textes, die sich zum einen aus dem von ihm vorgenommenen kulturspezifischen Aufbau von Einzelscenes ergibt, darüber hinaus jedoch durch Vorwissen und Erwartungen des Lesers entscheidend beeinflusst werden kann. (1990: 225)

[...] who arrives at a particular understanding of the text as based on a reading strategy. This strategy aims at creating a complete scene (complete understanding) of a text, which partly results from his/her own activation of culture-specific individual scenes, but can also be triggered by previous knowledge or expectations. (translation MSH.)

The concept of "model reader" seems particularly appropriate for the postcolonial text: in our discussion of the short passage from Midnight's Children quoted above (Rushdie 1981: 192-193), we differentiated, for example, between the "European reader" and the "scholar proficient in Indian languages" , following Prasad (1999). A novelist may write with a particular readership (model reader) in mind, or simply for self-expression, but a translator will almost invariably have a conception of the model reader envisaged 
for the target text. (S)he may have received instructions from the publisher or author, or may have conceived her/his model on the basis of some explicit aims. In our discussion of Indian postcolonial texts, the concept of model reader will be used to reinforce our analysis.

\title{
4. Sethu's Pandavapuram in English translation
}

Sethu is the pen-name of Sethumadhavan, born in Chendamangalam, Kerala in 1942, by profession a banker, now a well-known Malayalam novelist. Harris writes in his Introduction to the English translation of Pandavapuram:

\begin{abstract}
"Last night, as I lay waiting for the usual nightmare, Pandavapuram came into my mind, scattering the many-coloured glass pieces of extraordinary memories." This opening sentence would be immediately recognized by the informed reader of Malayalam fiction, for it bears the special stamp of Sethu's narrative genius, with its unmistakable predilection toward weird remembrances, nightmarish visions and inscrutable turns of events. Sethu is one of those writers who bring to bear upon their works a sense of the impossible, or the unknowable, together with a haunting quality, that is, though rooted in the mundane and the routine, remarkable for the way it calls up a subtext of profound psychological, anthropological and, at times, occult or mystical significance. Pandavapuram is an accomplished work of this kind, and it has an important place in the history of Malayalam fiction. (in Sethumadhavan 1995: vii)
\end{abstract}

The protagonist of Pandavapuram is Devi, a young schoolteacher deserted by her worthless husband Kunhikuttan. Left to fend for herself and her small son, she begins to imagine a new past and present revolving round herself, her husband and imagined lovers in a makebelieve town she calls Pandavapuram. Much of the story is actually set in the house of her husband's family in Kerala and centres round scenes and dialogue with an imaginary lover she has summoned from Pandavapuram. It is a world in which the borderlines between dream and reality, logic and irrationality, past and present disappear, and the structure of the novel reflects the alternating realms of experience, varying both in time and narrative perspective.

By writing in the regional language Malayalam, Sethu identifies his model reader as one familiar with the culture and daily life of Kerala, one who would also recognize the social criticism present in the work. The English translation appeared in 1995 in the series Modern Indian Novels in Translation, sponsored by an industrial house in India and published by Macmillan India. The project editor Mini Krishnan describes the series in his General Preface as follows:

Whatever our quarrels and shifting factions, all Indians know that they have a complex, stable system of values, beliefs and practices which - though forged long ago - has never really been interrupted. It still underlies the surface differences and makes them comprehensible. Our programme of trans- 
lations is an exploration of this Indian tradition which is one of humankind's most enduring attempts to create an order of existence that would make life both tolerable and meaningful.

The method we have adopted is to translate selections from the corpus of fiction Indians have created after their Independence (1947). It is our hope that these novels will express most of the ideas, customs, unquestioned assumptions and the persistent doubts that have characterised Indian life for at least a thousand years, and, more recently, after the impact of western ways of thinking on it. (in Sethumadhavan 1995: v)

With this last sentence Krishnan characterizes the series as postcolonial literature, but the English versions of these stories from various Indian languages, are clearly seen as translations in the classical sense and not hybrid texts. With his final remark "Some of the footnotes may seem excessive, but they have been prepared with non-Indian readers in mind" (1995: v) Krishnan also identifies the envisaged model reader as a non-Indian unfamiliar with Indian daily life and culture. About the translator Prema Jayakumar, born in 1952, we learn on the back cover of the volume that she "studied English Literature and now works in a bank"; she has translated short stories and two novels from Malayalam.

The English text reveals a number of translation strategies to the nonIndian scholar. One is the use of footnotes, indicated above. These notes are all brief, but fairly numerous, and they usually concern culture-bound items, as this example shows:

"Did he run away because he fought with his wife?"

"Fought with his wife? What a joke." Unni Menon spat a long stream of red out through the window. Red stars gleamed on the white sand. "There is some dignity in a fight. Is marriage a game? His stupidity hardly bears discussion. He kept having doubts about his wife. If she put kohl ${ }^{1}$ in her eyes, if she wore a pottu ${ }^{2}$, if she wore a new sari, he would get suspicious. He felt that his wife's family had tricked him into marrying her by giving him some magic potion. Some puja ${ }^{3}$ was going on when he went there to see her. The pujari ${ }^{4}$ gave him a plantain. As soon as he ate it, he started feeling odd. He felt that he wanted to marry only this girl. According to him this was because they had put some sort of spell in that plantain."

(Sethu, Pandavapuram: 21)

\section{Footnotes:}

${ }^{1}$ Collyrium, a paste used to make the eye look darker and brighter.

${ }^{2}$ Decorative mark worn on the forehead by single and married women, not widows.

${ }^{3}$ Worship, the rites of worship.

${ }^{4}$ Priest, one who conducts the worship.

In the case of kohl, the meaning clearly emerges from the context, and the footnote synonym collyrium seems more unfamiliar than the term it is meant to clarify (it is not entered in the Oxford Advanced Learner's Dictionary, but is defined in Collins English Dictionary as "a technical name for eyewash"). Besides, even the non-Indian reader may wonder if the other examples 
actually need a footnote: pottu and puja could be glossed in the text itself (by adding "on her forehead" or "sacred" respectively), and the meaning of pujari can then be derived from the context. A substantial problem with the footnotes, apart from the fact that they may jar in a literary text, is that each item is only explained once, and if the reader is not already familiar with it, he/she has to either memorize it or make a note of the page on which the footnote is located. In the case of the complex religious and mythological terminology this can become a problem: where the item cannot be explained in the text, the interested non-Indian reader might prefer a glossary at the end of the volume.

Another strategy concerns the variations of Malayalam forms of address in dialogue:

"Shyamaledathi is greedy. Whatever she sees, she wants," Raghu said. "Amma is always scolding her for that."

"Why do you call her 'edathi'? She is your aunt, isn't she?"

"She doesn't like me calling her 'aunt'. She says she prefers to be called 'edathi'."

He could hear voices from outside. Devi was probably scolding Shymala. (Sethu, Pandavapuram: 43)

In a previous footnote (p. 36) the reader has been informed that edathi means 'elder sister', which can be added as a suffix to the name as here. A similar kinship term, which can also be added as a suffix to the name is ettan for 'elder brother', but it can also be suffixed to the name of the husband (fn.p.31), giving the form "Kunhikuttettan" for the name Kunhikuttan. A further variant is Kunhunnimaman meaning 'Kunhunni Uncle' (p.93). Similarly terms like babuji (fn.p.57, a term of respect, meaning 'master'), muthassi (fn.p.17, 'grandmother') and amma (fn.p.32, 'mother') are used untranslated in the text, as in the above passage, after an initial footnote explanation. The result is a text, describing a South Indian setting, which basically observes the norms of Standard English, but is at the same time interspersed with untranslated forms of address and constantly changing names, sometimes to the cost of intratextual coherence.

That the text has been translated into a non-mother tongue is sometimes betrayed by what for the non-Indian reader are lexically incoherent elements, such as the noun paramour to refer to Devi's imaginary male lovers and the somewhat derogatory adjective toothy to describe her radiant facial expression. For a European reader the dialogue may also seem formal and wooden, but we should bear in mind that formal English was passed on to the Indians by the upper-class British colonizers, besides, it is quite coherent with an Indian background (see Villareal 1994: 72-73; Snell-Hornby 1997a: 54-55). The descriptive and reflective passages, as illustrated by the novel's first sentence quoted in Harris's introduction (cf. above), are highly evocative and sometimes even lyrical, as the following passage might also show: 
The biggest curse is the ability to dream.

I am becoming helpless here. Like the faces which melt into the misty air, like the footprints which are blurred by the wind. Like the black seeds which scatter on all sides when dried yellow pods break, like the yellow flowers in the flower beds which smile once in the month of Aswin ${ }^{5}$ and then fade immediately, like the birds which fall with a cry from the trees in the heavy dusty wind [...] (Sethu, Pandavapuram: 56)

Footnote:

${ }^{5}$ The Sanskrit month which falls in October-November

\section{The God of Small Things as a postcolonial hybrid text}

If we compare the short passage from Rushdie's Midnight's Children, quoted above, or the longer passage from Arundhati Roy's The God of Small Things at the beginning of this essay with the examples from the English version of Pandavapuram, the essential difference between the declared translation and the hybrid text should begin to emerge. The first adheres basically to the standard norms of the target language, here English, making the narrative transparent for the reader by giving footnote explanations of strange language forms or culture-bound items before they are retained in the text. The hybrid texts of Rushdie and Roy on the other hand, create their own 'norms' of English, including both strange language forms and culturebound items, embedded in a dense or truncated syntax, as well as exuberant imagery that stretches the non-Indian reader's power of comprehension without offering any form of explanation.

By writing her first novel in English, Arundhati Roy consciously aims at a model reader from the world market, most likely a non-Indian. The God of Small Things shows some similarities with Pandavapuram but also has basic differences. Both are set in a village in Kerala and describe the personal fate of a character within a family in decline, but whereas in Sethu's story the family and setting are traditional (the only concrete signs of colonialism are the descriptions of railways and the industrial development in Pandavapuram), Roy's family is a real colonial mix. It includes the Oxfordeducated uncle Chacko, his English wife Margaret and their daughter Sophie on the one hand, and the more traditional grandmother Mammachi on the other, while focussing on the half-emancipated but luckless Ammu (mother of Rahel, through whose perspective most of the story is told) and her doomed love affair with the 'Untouchable' carpenter and Communist activist Velutha, as well as his horrific end. Both stories depict the "complex, stable system of values, beliefs and practices" of Indian tradition mentioned by Mini Krishnan (1995: v), but these are far more sharply called into question, even satirized by Arundhati Roy. Both stories have a complex narrative structure, with shifts in time, place and narrative perspective reflecting the alternating realms of experience, but these are more complex and subtle in the longer novel by Roy. And in both stories the language is highly evoca- 
tive, containing elements of the local Malayalam language and culture, though in Roy's innovative hybrid text these are fused together far more boldly than they are in Jayakumar's translation.

The passage quoted at the beginning of this essay shows the jarring contact of two cultural codes, when the Indian cook Kochu Maria meets the child Sophie Mol just after she has arrived from Europe: Sophie's reaction, along with the comments of the two adult women, the European Margaret and the Indian Ammu, illustrate Roy's style of light satirical narrative. This is also reflected in her creative handling of language generally and in the authorial comment: "An embarrassed schoolteacher-shaped hole in the Universe." The first two sentences of the passage describe Ammu's sevenyear-old twins, Rahel and Estha, whereby strange-sounding elements like "Airport Fairy frocks", "Love-in-Tokyos" and "backward-reading habits" refer to passages in previous parts of the novel and are hence clear for the attentive reader. Such intratextual reference and reiteration is one of the most salient characteristics of Roy's technique, and individual phrases of this kind often have a symbolic meaning, acting as signals in the complex unfolding of the story.

In contrast to Pandavapuram, the dialogue is informal, natural, idiomatic and often as dynamic as stage dialogue; not only in this passage, but throughout the novel. Even when Indians converse among themselves there are no pedantic monologues of the kind quoted above from Unni Menon. Furthermore, as regards culture-bound items and Malayalam forms of address or items of Malayalam, these are interwoven into the immediate context, which often clarifies them; in some cases they are transcoded or explained immediately, sometimes only at a later stage of the narrative (creating considerable suspense for the reader). A few examples are:

The buses all had girls' names. Lucykutty, Mollykutty, Beena Mol. In Malayalam, Mol is Little Girl and Mon is Little Boy. Beena Mol was full of pilgrims who'd had their heads shaved at Tirupati.

Rahel tried to walk past unnoticed. It was absurd of her to have imagined that she could.

“Aiyyo, Rahel Mol!”, Comrade K.N.M. Pillai said, recognizing her instantly. "Orkunnilley? Comrade Uncle?"

"Oower," Rahel said.

Did she remember him? She did indeed.

The Arrivals Lounge was a press of love and eagerness, because the BombayCochin flight was the flight that all the Foreign Returnees came on.

Their families had come to meet them. From all over Kerala. On long bus journeys. Fram Ranni, from Kumili, from Vizhinjam, from Uzhavoor. Some of them had camped at the airport overnight, and had brought their food with them. And tapioca chips and chakka velaichathu for the way back.

They were all there - the deaf ammoomas, the cantankerous, arthritic appoopans, the pining wives, scheming uncles, children with the runs. The fiancées to be reassessed. The teacher's husband still waiting for his Saudi visa. The teacher's husband's sisters waiting for their dowries. The wirebender's pregnant wife. (Roy, The God of Small Things: 60, 128 \& 138) 
Another salient characteristic of Roy's style is the rich and exuberant imagery, which intertwines both exotic cultural items and seemingly mundane features of everyday life, with bold syntactic deviations from standard language norms. Here a description of a scene at Cochin railway station:

She was standing on the platform of the Cochin Harbour Terminus, her face turned up to the train window. Her skin grey, wan, robbed of its luminous sheen by the neon station light. Daylight stopped by trains on either side. Long corks that kept the darkness bottled in. The Madras Mail. The Flying Rani.

Rahel held by Ammu's hand. A mosquito on a leash. A Refugee Stick Insect in Bata sandals. An Airport Fairy at a railway station. Stamping her feet on the platform, unsettling clouds of settled station-filth. Until Ammu shook her and told her to Stoppit and she Stoppited. Around them the hostling-jostling crowd.

Scurrying hurrying buying selling luggage trundling porter paying children shitting people spitting coming going begging bargaining reservationchecking.

Echoing stationsounds. (300)

The descriptions of Kerala's lush tropical landscape are particularly evocative and dense with imagery, as in this description of the river as Rahel experiences it after an absence of twenty-three years:

Despite the fact that it was June, and raining, the river was no more than a swollen drain now. A thin ribbon of thick water that lapped wearily at the mud banks on either side, sequinned with the occasional silver slant of a dead fish. It was choked with a succulent weed, whose furred brown roots waved like thin tentacles under water. Bronze-winged lily-trotters walked across it. Splay-footed, cautious.

Once it had had the power to evoke fear. To change lives. But now its teeth were drawn, its spirit spent. It was just a slow, sludging green ribbon lawn that ferried fetid garbage to the sea. Bright plastic bags blew across its viscous, weedy surface like subtropical flying-flowers. (124)

On other occasions, the imagery is used poetically, with lyrical rhythm and charm: the passage from the final scene of the novel (which in narrated time actually precedes the catastrophe) is an apt illustration, and it reminds one immediately of the description quoted above from Pandavapuram:

That first night, on the day that Sophie Mol came, Velutha watched his lover dress. When she was ready she squatted facing him. She touched him lightly with her fingers and left a trail of goosebumps on his skin. Like flat chalk on a blackboard. Like breeze in a paddyfield. Like jet-streaks in a blue church sky. He took her face in his hands and drew it towards his. He closed his eyes and smelled her skin. Ammu laughed.

Yes, Margaret, she thought. We do it to each other too. (340) 


\section{The God of Small Things in German translation}

Both Midnight's Children and The God of Small Things were sensational bestsellers, and both were awarded the Booker Prize (in 1981 and 1997 respectively): the aim of the German translation was therefore clearly to make the novels accessible to a German readership and repeat the commercial success on the German market. There are however fundamental problems involved in translating a hybrid English postcolonial text for another European target culture. In the case of German a major difficulty lies in the lack of a comparable colonial past with the corresponding plurality of associations, language usages and cultural backgrounds. The envisaged German model reader may be cultivated, interested and well-informed, but detailed knowledge of the countries and people figuring in the novels cannot be presupposed. Apart from this, the multi-layered nature of the language of the source text proves a problem that sometimes seems insurmountable. Let us first look at Karin Graf's German translation of the passage quoted above from Midnight's Children:

Padmas Geschichte (in ihren eigenen Worten erzählt und ihr wieder vorgelesen, damit sie sie augenrollend, laut jammernd, brustschlagend bestätige): „Mein eigner dummer Stolz und meine Eitelkeit, Saleem Baba, sind der Grund, dass ich von dir weggelaufen bin, obwohl die Arbeit hier gut ist und du so dringend jemand brauchst, der auf dich aufpasst! Aber schon nach kurzer Zeit wollte ich unbedingt wieder zurückkommen.

(Rushdie/Graf, Mitternachtskinder: 253)

In his discussion of the English version, Prasad refers to the "layered nature of otherness" and diagnoses the spoken language as "a transcript of a speech made by an illiterate woman" (1999: 52), but neither is recognizable in the German text. Padmas' language is grammatically correct, formal German; there is no sign whatsoever of any transcoding from Urdu nor of the coinage "looker-after", and the signals in the form of address identified by Prasad (despite limited explanations in the Glossary at the end of the novel) will surely be unrecognizable for a non-specialist German reader. In other words, the language has been neutralized into a linguistically correct and stylistically unified formal German statement.

Similar assessments can be made, sometimes with more sometimes with less validity, of other German translations of Salman Rushdie's novels (see Snell-Hornby 1997b: 275-276): indeed, it is a major challenge in translating postcolonial hybrid texts to avoid neutralizing the "layered nature of otherness" into a uniformly 'correct' literary language. Sometimes this also seems to happen in Anette Grube's German version of Roy's novel, Der Gott der kleinen Dinge, as a brief first impression might indicate: Roy's subtle and grammatically bold dedication of her novel "For Mary Roy who grew me up" has been neutralized into "Für Mary Roy, die mich aufzog". In all fairness, however, we must point out that the translator has usually tried to meet the challenge of Roy's norm-stretching creativity and has often had the 
courage to produce unusually creative results herself. First, let us look at her version of the passage where Kochu Maria greets Sophie Mol:

Kleine Teufel waren schlammbraun und trugen Flughafen-Feenkleider und hatten Beulen auf der Stirn, die sich womöglich zu Hörnern auswuchsen. Fontänen in Love-in-Tokyos. Und die Gewohnheit, rückwärts zu lesen.

Wenn man sich die Mühe machte, entdeckte man den Satan in ihren Augen. Kochu Maria nahm Sophies Hände in ihre, die Handflächen nach oben, hob sie an ihr Gesicht und atmete tief ein.

„Was macht sie da?“ wollte Sophie Mol wissen, ihre zarten Londoner Hände im Griff schwieliger Ayamenem-Hände. „Wer ist sie und warum riecht sie an meinen Händen?“"

„Sie ist die Köchin“, sagte Chacko. „Das ist ihre Art, dich zu küssen.“

„Küssen?“ Sophie Mol war nicht überzeugt, aber interessiert.

„Wie wunderbar!“, sagte Margaret Kochamma. „Eine Art Schnüffeln. Machen das auch Männer und Frauen miteinander?"“

Sie hatte nicht gewollt, dass es so klang, wie es klang, und wurde rot. Ein verlegenes schullehrerinnenförmiges Loch im Universum.

„Die ganze Zeit", sagte Ammu etwas lauter als das sarkastische Murmeln, das sie beabsichtigt hatte. „So machen wir Kinder“.

(Roy/Grube, Der Gott der kleinen Dinge: 207)

Particularly phrases like "ein verlegenes schullehrerinnenförmiges Loch im Universum" indicate that the translator is able and willing to re-create the language "norms' designed by the author of the source text. If we consider the "layered nature of otherness" and the linguistic signals resulting from the insertion of elements of Malayalam, distinct strategies emerge. The translation has neither footnotes nor a glossary, but Roy's strategy of explaining in context has been adopted and in part extended, as the explanation of the names of buses shows. Here, the reader is told that Malayalam is a language:

Alle Busse hatten Mädchennamen. Lucy Kutty, Molly Kutty, Beena Mol. Mol ist Malayalam und bedeutet kleines Mädchen, und Mon heißt kleiner Junge. (76)

In many cases a Malayalam word is italicized in the German version, but often the translator is helped by the author's strategy of repeating some terms in English, as in the sudden meeting with Comrade Pillai:

Rahel versuchte, unbemerkt vorbeizugehen. Der Gedanke, das wäre möglich, war absurd.

„Aiyyo Rahel Mol!“ sagte Genosse K. N. M. Pillai, der sie augenblicklich erkannt hatte. „Orkunnilley? Genosse Onkel?“

"Oower", sagte Rahel.

Erinnerte sie sich an ihn? Sie erinnerte sich. (151)

In this particular example one could actually criticize the reduction of the satirical effect originally created by the sarcastic narrative tone in the last sentence of the English version: the person who had given Rahel so noncha- 
lant a greeting was after all the one who had brought disaster on her family, and German has better syntactic means of expressing this than the literal translation given here, e.g.: "Ob sie sich an ihn erinnerte? Allerdings."

Frequently, culture-bound items are simply left untranslated and italicized, as in the airport scene:

In der Ankunftshalle drängelten sich Liebe und Eifer, denn der Flug BombayCochin war der Flug, mit dem alle nach Hause zurückkehrten, die im Ausland arbeiteten.

Ihre Familien waren gekommen, um sie zu begrüßen.

Aus ganz Kerala. In langen Busfahrten. Aus Ranni, aus Kumili, aus Vizhinjam, aus Uzhavoor.

Manche hatten im Flughafen übernachtet und ihr Essen mitgebracht. Und Tapioka-Chips und chakka velaichatu für den Rückweg.

Alle waren sie da - die tauben ammoomas, die mürrischen, arthritischen appoopans, die sehnsüchtigen Ehefrauen, die intrigierenden Onkel, die Kinder mit Durchfall. Die verlobten Mädchen, die neu eingeschätzt werden mussten. Der Mann der Lehrerin, der noch auf sein Visum für Saudi-Arabien wartete. Die Schwestern des Mannes der Lehrerin, die auf ihre Mitgift warteten. Die schwangere Frau des Stahlarbeiters. (161)

Still, the context obviously makes clear that some words are place-names, some refer to food and others to people. In the scene at the railway station the observations made so far are confirmed:

Ammu hielt Rahels Hand. Eine Mücke an der Leine. Ein Flüchtlingsstechinsekt in Bata-Sandalen. Eine Flughafenfee in einem Bahnhof. Stampfte mit den Füßen auf dem Bahnsteig auf, wirbelten Wolken von niedergelassenem Bahnhofsstaub auf. Bis Ammu sie schüttelte und ihr sagte, sie solle aufhören, und sie aufhörte. Um sie herum die drängelnde, rempelnde Menge.

Flitzen eilen kaufen verkaufen Gepäck schleppen Gepäckträger zahlen Kinder scheißen Menschen spucken aus kommen gehen betteln feilschen überprüfen Reservierungen.

Wiederhallende Bahnhofsgeräusche. (338)

On the one hand, a creative form from childhood language, "told her to Stoppit and she Stoppited", has been neutralized into correct standard German, on the other, this is compensated by the creative formation of compounds and at least the attempt to reproduce the "stationsounds" by unmarked infinitive forms. However, whether the translation is as effective here as the English, is another matter, and it would be beyond the scope of this contribution to embark on that discussion.

The translation of landscape descriptions with their dense exotic imagery and their bold compound forms seems successful on the whole, as this description of the river shows:

Obwohl es Juni war und regnete, war der Fluss nur mehr ein angeschwollenes Rinnsal. Ein schmales Band dickflüssigen Wassers, das müde an den Lehmufern zu beiden Seiten leckte, gelegentlich trieb ein toter Fisch vorbei, 
eine silberne Paillette. Er wurde erstickt von einem sukkulenten Unkraut, dessen pelzige braune Wurzeln unter Wasser winkten wie dünne Tentakel. Bronzeflüglige Wasserläufer stakten darüber. Mit gespreizten Füßen, vorsichtig.

Einst hatte er die Macht besessen, Furcht zu erregen. Leben zu verändern. Aber jetzt waren ihm die Zähne gezogen, sein Geist war erloschen. Er war nur noch ein träges, schlammiges grünes Batistband, das stinkenden Abfall ins Meer schwemmte. Bunte Plastiktüten wehten über seine zähflüssige, unkrautverseuchte Oberfläche wie fliegende subtropische Blumen. (146)

Here again however, some innovative compound forms may have been effectively re-created (e.g. "bronzeflüglige Wasserläufer"), but there are bold grammatical innovations in the English text that have been neutralized. One example is "sequinned with the occasional silver slant of a dead fish", which has been translated into the more banal expression "trieb ein toter Fisch vorbei, eine silberne Paillette". Similarly, the complex and rhythmical metaphor of the "sludging green ribbon lawn that ferried fetid garbage to the sea" has been reduced to the more prosaic "schlammiges grünes Batistband, das stinkenden Abfall ins Meer schwemmte".

\section{Conclusion}

If translation is re-creation, this is particularly true for the postcolonial hybrid text. Since the source text is already a blend of cultural and linguistic elements occupying a 'space in between', the target text will have to follow suit if it is to reflect this. The 'new English' with its own individual language 'norms', along with the many 'exotic' culture-bound items, which in their entirety often carry the message of the text, present a genuine challenge for the translator's capacity of understanding, and for his or her creative powers. The above analysis has shown that it is quite possible and even desirable for these to be created anew in the target text, in an act, as Prasad put it in the passage quoted above, "not just of bearing across but of fertile coming together."

\section{Bibliography}

\section{Primary texts}

Roy, Arundhati (1997). The God of Small Things. London: Harper/Flamingo.

Roy, Arundhati (1997). Der Gott der kleinen Dinge. Roman. (tr. Anette Grube). München: Blessing.

Rushdie, Salman (1981). Midnight's Children. London: Cape/Picador.

Rushdie, Salman (1983). Mitternachtskinder. Roman. (tr. Karin Graf). München: Piper.

Sethu(madhavan) (1995). Pandavapuram. (tr. from the Malayalam original by Prema Jaykumar). Madras: Macmillan. 


\section{Secondary texts}

Ammann, Margret (1990). "Anmerkungen zu einer Theorie der Übersetzungskritik und ihrer praktischen Anwendung." TEXTconTEXT 5, 205-250.

Bassnett, Susan \& Harish Travedi (eds) (1999). Post-colonial Translation. Theory and Practice. Translation Studies. London/New York: Routledge.

Bhaba, Homi K. (1994). The Location of Culture. London/New York: Routledge.

Fillmore, Charles J. (1977). "Scenes-and-frames semantics." A. Zampolli (ed.) (1997). Linguistic Structures Processing. Amsterdam: New Holland, 55-82.

Grbić, Nadja \& Michaela Wolf (eds) (1997). Text - Kultur - Kommunikation. Translation als Forschungsaufgabe. Festschrift aus Anlass des 50jährigen Bestehens des Instituts für Übersetzer- und Dolmetscherausbildung an der Universität Graz. Tübingen: Stauffenburg.

Grosman, Meta et al. (eds) (2000). Translation into Non-Mother Tongues. In Professional Practice and Training. Tübingen: Stauffenburg

Mehrez, Samia (1992). "Translation and the postcolonial experience: The francophone North African text." Lawrence Venuti (ed.) (1992) Rethinking Translation. Discourse, Subjectivity, Ideology. London/New York: Routledge, 120-138.

Prasad, G.J.V. (1999). "Writing translation: the strange case of the Indian English novel." Susan Bassnett \& Harish Travedi (eds) (1999). Post-colonial Translation. Theory and Practice. Translation Studies. London/New York: Routledge, 41-57.

Schäffner, Christina \& Beverly Adab (1997). "Translation as intercultural communication - Contact as conflict.” M. Snell-Hornby, Z. Jettmarová \& K. Kaindl (eds) (1997). Translation as Intercultural Communication. Selected Papers from the EST Congress - Prague 1995. Amsterdam/Philadelphia: Benjamins, 325-337.

Schäfer, Jürgen (ed) (1981). Commonwealth-Literatur. Düsseldorf/Bern: Bagel/Francke.

Snell-Hornby, Mary (ed.) (1986). Übersetzungswissenschaft - Eine Neuorientierung. Zur Integrierung von Theorie und Praxis. Tübingen: Francke.

Snell-Hornby, Mary (1997a). "Released from the grip of Empire: lingua franca as target culture?”. M.A. Vega \& R. Martín-Gaitero (eds) (1997). La palabra vertida. Investigaciones en torno a la traducción. Madrid: Complutense, 45-56.

Snell-Hornby, Mary (1997b). “'Jack McWorld, M.A.': Translatoren um die Jahrtausendwende" - N. Grbić \& M. Wolf (eds) (1997). Text - Kultur Kommunikation. Translation als Forschungsaufgabe. Festschrift aus Anlass des 50jährigen Bestehens des Instituts für Übersetzer- und Dolmetscherausbildung an der Universität Graz. Tübingen: Stauffenburg, 265-279.

Snell-Hornby, Mary (1999). "Communicating in the Global Village: On Language, Translation and Cultural Identity." Current Issues in Language and Society 6(2), 103-120.

Snell-Hornby, Mary (2000). “ 'McLanguage': The identity of English as an issue in translation today." M. Grosman, M. Kadrić, I. Kovačič \& M. Snell-Hornby (eds) (2000). Translation into Non-Mother Tongues. In Professional Practice and Training. Tübingen: Stauffenburg, 35-44.

Snell-Hornby, Mary, Jett-marová, Zuzana \& Klaus Kaindl (eds) (1997). Translation as Intercultural Communication. Selected Papers from the EST Congress Prague 1995. Amsterdam/Philadelphia: Benjamins.

Stickel, Gerhard (2003). "Zur derzeitigen Situation des Deutschen im vielsprachigen Europa und im Kontext kommunikativer 'Globalisierung'." Paper presented 
at Blickwechsel. XI. ALEG-Kongress (Sao Paulo - Paraty - Petrópolis, 27 September- 3 October 2003).

Vannerem, Mia \& Mary Snell-Hornby (1986). "Die Szene hinter dem Text: 'scenesand-frames semantics' in der Übersetzung.” M. Snell-Hornby (ed.) (1986). Übersetzungswissenschaft - Eine Neuorientierung. Zur Integrierung von Theorie und Praxis. Tübingen: Francke, 184-205.

Vega, M.A. \& R. Martín-Gaitero (eds) (1997). La palabra vertida. Investigaciones en torno a la traducción. Madrid: Complutense.

Venuti, Lawrence (ed.) (1992). Rethinking Translation. Discourse, Subjectivity, Ideology. London/New York: Routledge.

Vermeer Hans J. \& Heidrun Witte (1990). Mögen Sie Zistrose? Scenes \& frames \& channels im translatorischen Handeln. Heidelberg: Groos.

Villareal, Corazon D. (1994). Translating the Sugilanon: Reframing the Sign. Quezon City: University of the Philippines Press. 